\section{RESENHAS CRITICAS}

PATTO, Maria Helena Souza A

Queiroz, 1990. 385p.

Mana Helena Souza Patto elegeu como objeto de estudo, nesta obra, o fracasso escolar das crianças das camadas populares. Ela justifica a sua escolha considerando que a reprodução e a evasão na escola pública de primeiro grau, durante várias décadas, assumem proporções inaceitáveis e que as diversas tentativas de solucionar esse problema - como as reformas educacionais, projetos de pesquisa na área e um conjunto de medidas técnico-administrativas tomadas pelos órgãos oficiais - têm se mostrado ineficientes ao longo de sessenta anos.

A sua obra está organizada em duas partes. Na primeira, a autora faz uma revisão crítica da literatura sobre as causas das desigualdades educacionais na sociedade brasileira e uma análise das raízes históricas das concepções sobre o fracasso escolar. $\mathrm{Na}$ segunda parte, a autora analisa os dados coletados numa pesquisa de campo, na qual observou, na escola, em casa e no bairro, crianças moradoras da periferia de São Paulo, que são alunos multirrepetentes de uma escola pública de primeiro grau.

Partindo do princípio de que um modelo positivista de produção de conhecimento nas Ciências Humanas e Sociais não comporta a complexidade da vida humana (além de se deter na aparência dos fenômenos e, portanto, gerar pseudoconhecimentos), Patto utiliza o materialismo histórico como referencial teórico e deti- do fracasso escolar. São Paulo: T. A.

ne como necessário "conhecer, pelo menos em seus aspectos fundamentais, a realidade na qual se engendrou uma determinada versão sobre as diferenças de rendimento escolar existentes entre crianças de diferentes origens sociais".

Para isso, ela faz uma revisão crítica do discurso que fundamenta a literatura voltada para esse tema -no que ele "diz", no que ele "não diz" e no que se "contradiz" - e examina as raízes históricas e o contexto socioeconômico e político no qual a representação de pessoas das camadas populares se desenvolveu, impregnada de preconceitos e de estereótipos sociais.

Essa revisão a conduz, necessariamente, a uma análise do advento das sociedades industriais capitalistas, dos sistemas nacionais de ensino e das Ciências Humanas, especialmente da Psicologia. Nesse contexto, tendo como pano de fundo o ideário liberal e, conseqüentemente, estando presente o discurso da crença na possibilidade de uma sociedade igualitária e democrática, a escola funciona como instrumento de ascensão e de prestígio social.

Nessa época a Psicologia Científica, através dos resultados nos testes de inteligência oferece a explicação e a mensuração das diferenças individuais, sedimentando a idéia de que os mais capazes ocupam as meIhores posições na sociedade. Os lugares sociais, portanto, seriam ocupa- 
dos com base no mérito e esforço pessoal, e esse seria o único critério legítimo de seleção educacional e social.

A autora enfatiza que, na análise das dificuldades de aprendizagem escolar, a Psicologia, influenciada por uma visão organicista das aptidões humanas - carregada de pressupostos racistas e elitistas - e por uma concepção atenta às influências ambientais, produz, conseqüentemente, uma explicação impregnada dessa ambigüidade, que será uma característica presente no discurso sobre as causas do fracasso escolar, nos países capitalistas ao longo do século $X X$, fundamentando, inclusive, a "teoria da carência cultural".

Ao fazer uma análise ideológica dessa teoria, Patto enumera três causas apontadas, pela teoria, para as dificuldades de aprendizagem das crianças das camadas populares: as suas condições de vida, a inadequação da escola pública em lidar com esse aluno concreto, e, por parte da professora, a falta de sensibilidade e de conhecimento da realidade vivida pelos seus alunos, em conseqüência da distância entre a sua cultura e a deles.

Considerando o fracasso escolar como um processo psicossocial complexo, e a fim de questionar alguns desses conhecimentos ditos "científicos", que fundamentam a teoria da carência cultural das crianças das camadas populares, Patto permanece numa escola pública de primeiro grau e num bairro da periferia da cidade de São Paulo, realizando observações em vários contextos e entrevistas formais e informais com todos os en- volvidos no processo educativo que nela se desenrola, incluindo os alunos e suas famílias.

Buscando um enquadramento teórico que tivesse como pressuposto a determinação histórico-social da ação humana, a autora encontrou no conceito sociológico de "vida cotidiana" (fundamentado pela pensadora marxista Agnès Heller), subsídios que a ajudassem a responder às seguintes perguntas: Quem são estas crianças? Como vivem na escola e fora dela? Como vivem na escola e como participam do processo que resulta na impossibilidade de se escolarizarem?

Constatando que nas pesquisas sobre a escola e sobre o fracasso escolar as crianças são reduzidas a números frios e impessoais e, conseqüentemente, tornam-se as grandes ausentes, Patto, convivendo com quatro alunos muitirepetentes, deu voz a esses sujeitos e revelou o discurso dessas crianças, recusando-se a fazer um discurso "sobre" elas. Assim, a proposta metodológica utilizada pela autora possibilitou-lhe confrontar a leitura dos profissionais da escola com o discurso de seus alunos e de suas famílias: alguns laudos psicológicos dessas crianças com as observações feitas por ela e por suas auxiliares de pesquisa em sala de aula e nas casas das crianças, em relação ao fracasso escolar.

Essa confrontação permitiu à autora elaborar algumas conclusões a respeito do tema, fazendo uma revisão crítica das teorias do déficit e da diferença cultural:

- a inadequação da escola decorre, principalmente, de sua má qualidade, da representação negativa que 
os seus profissionais têm da capacidade dos alunos, conseqüência da desvalorização social dos seus usuários mais empobrecidos;

- o fracasso da escola pública elementar é o resultado inevitável de um sistema educacional congenitamente gerador de obstáculos à realização de seus objetivos;

- esse fracasso é administrado por um "discurso científico escudado em sua competência, naturaliza esse fracasso aos olhos de todos os envolvidos no processo";

-".-a rebeldia pulsa no corpo da escola e a contradição é uma constante no discurso de todos os envolvi- dos no processo educativo; mais que isto, sob uma aparente impessoalidade, pode-se captar a ação constante da subjetividade. A burocracia não tem o poder de eliminar o sujeito; pode, no máximo, amordaçá-lo."

A obra de Patto configura-se como leitura imprescindível aos pesquisadores do fracasso escolar e a todos os educadores comprometidos com a democratização do ensino para as camadas populares.

Maria das Graças de Castro Senna Universidade Federal de Minas Gerais

(UFMG) 